\title{
Analisis gambaran histogram dan densitas kamar pulpa pada gigi suspek pulpitis reversibel dan ireversibel dengan menggunakan radiografi cone beam computed tomography (Histogram and density analysis of irreversible and reversible pulpitis- suspected tooth using cone beam computed tomography radiography)
}

\author{
Lusi Epsilawati, Suhardjo Sitam, Sam Belly, Fahmi Oscandar \\ Departemen Radiologi Dentomaksilofasial, \\ Fakultas Kedokteran Gigi Universitas Padjadjaran \\ Bandung, Indonesia
}

\begin{abstract}
Inflammation of the pulp is most common and difficult to diagnose. For it radiographs is necessary. One attempt to do is to assess its histogram and density. Radiography equipment that has the ability to analyze is cone beam computed tomography (CBCT). The purpose of this study is to analyze radiograph of the pulp chamber histogram: peak value, grayscale and trends, as well as the density on the condition reversible and irreversible pulpitis condition. The population of this descriptive study is secondary data of CBCT-3D radiographs during 2012-2013. Selected sample of 75 data is reversible pulpitis, irreversible pulpitis 80 data, as well as 20 normal condition data as control. Data were analyzed by one way ANOVA and are presented in tables and graphs. The results showed that the value of the histogram under normal conditions showed a different significance for both the peak value of the reversible or irreversible pulpitis $(p=0.01)$. It is different with a grayscale value, showed no significant different between normal with reversible pulpitis $(p=0.997)$ and significantly different between normal and pulpitis reversible against pulpitis irrebversible $(p=0.03-0.01)$. There is a growing trend change is on the right direction of reversible and irreversible pulpitis. It was concluded that the irreversible pulpitis, density and histogram shows the direction of more luscent compared with normal and reversible pulpitis conditions.
\end{abstract}

Key words: reversible pulpitis, irreversible pulpitis, histogram, trend, grayscale, peak

\begin{abstract}
ABSTRAK
Inflamasi pada pulpa paling sering terjadi dan sulit untuk didiagnosis. Untuk itu pemeriksaan radiografi sangat diperlukan. Salah upaya yang dapat dilakukan adalah dengan melakukan penilaian terhadap histogram dan densitas. Peralatan radiografi yang dilengkapi kemampuan untuk menganalisis hal adalah cone beam computed tamography (CBCT). Penelitian ini dimaksudkan untuk menganalisis gambaran histogram kamar pulpa dilihat dari nilai peak, grayscale, dan trend, serta densitas pada kondisi pulpitis reversibel dan ireversibel. Populasi penelitian deskriptif ini berupa data sekunder radiografi CBCT-3D selama tahun 2012-2013. Sampel yang terpilih sebanyak 75 data pulpitis reversibel, 80 data pulpitis ireversibel, serta 20 data kondisi normal sebagai kontrol. Data yang terkumpul dianalisis dengan one way anova dan disajikan dalam bentuk tabel dan grafik. Hasil penelitian menunjukkan bahwa nilai histogram pada kondisi normal memperlihatkan signifikansi berbeda untuk nilai peak baik terhadap pulpitis reversibel ataupun ireversibel $(\alpha=0,01)$. Hal berbeda dengan nilai grayscale menunjukkan tidak signifikan berbeda antara normal dengan pulpitis reversibel $(\alpha=0,997)$, dan signifikan berbeda antara kondisi normal dan pulpitis reversibel terhadap pulpitis ireversibel $(\alpha=0,03-0,01)$. Terdapat perubahan trend semakin ke arah kanan, yaitu pada pulpitis reversibel dan ireversibel. Disimpulkan bahwa pada pulpitis ireversibel, densitas dan histogram menujukkan ke arah lebih lusent dibandingkan dengan kondisi normal dan pulpitis reversibel.
\end{abstract}

Kata kunci: pulpitis reversibel, pulpitis ireversibel, histogram, trend, graysacle, peak

Koresponden: Lusi Epsilawati, E-mail: lusifkg92@gmail.com

\section{PENDAHULUAN}

Kesehatan gigi dan mulut merupakan bagian dari kesehatan tubuh yang tidak dapat dipisahkan satu dengan yang lainnya, sebab kesehatan gigi dan mulut akan mempengaruhi kesehatan tubuh keseluruhan. ${ }^{1}$ Kebersihan gigi dan mulut yang tidak diperhatikan, akan menimbulkan masalah salah satunya karies. Karies gigi bersifat kronis dalam perkembangannya dan butuh waktu yang lama, sehingga sebagian besar penderita mempunyai potensi mengalami gangguan kelainan ini seumur hidup. ${ }^{2-4}$ Prevalensi kerusakan gigi di dunia yang tertinggi, terdapat di Asia dan
Amerika Latin, dan paling rendah terdapat di Afrika. Kerusakan gigi didominasi oleh karies, ${ }^{5,6}$ yang secara umum dikenal sebagai pulpitis. ${ }^{7,8}$

Pulpitis adalah peradangan jaringan pulpa gigi. Radang atau inflamasi adalah respon suatu organisme terhadap patogen dan jejas mekanis dalam jaringan, berupa rangkaian reaksi yang terjadi pada tempat jaringan yang mengalami cedera, seperti terinfeksi. Inflamasi adalah satu dari respon utama dari sistem kekebalan terhadapinfeksi dan iritasi. Pulpitis paling sering disebabkan oleh karies gigi yang menembus email dan dentin lalu mencapai pulpa, atau mungkin 
disebabkan adanya trauma. ${ }^{8}$ Ketika pulpa meradang, terjadi reaksi pada kamar pulpa yang memberikan efek pada saraf dan jaringan sekitarnya. Peradangan dapat dirasa sebagai rasa nyeri ringan hingga hebat tergantung pada tingkat keparahan peradangan dan respon tubuh, tidak seperti bagian lain dari tubuh yang rasa nyerinya dapat dibagi ke jaringan lunak di sekitarnya. ${ }^{9}$ Rongga pulpa merupakan bagian tubuh yang sangat tertutup, respon sistem kekebalan tubuh yang berkerja sangat sulit diredakan. ${ }^{10,11}$ Radiografi dental adalah sebuah gambaran yang dihasilkan dan digunakan untuk membantu menentukan kelainan atau diagnosis. Sebuah gambar radiografi dibentuk oleh sinar-X yang menembus organ pada tingkat yang berbeda, tergantung pada kepadatan anatomi. Gigi dengan karies terjadi perubahan pada kepadatan/ densitas tulang. ${ }^{9,10}$

Radiografi digital CBCT-3D, merupakan jenis radiografi yang mampu memperlihatkan detail dari gambaryang diambilnya. DalamCBCT, ditampilkan densitas atau kepadatan jaringan, berupa gambaran histogram. Pada kondisi pulpitis, terdapat banyak perubahan yang terjadipada jaringan pulpa termasuk bertambahnya cairan radang yang merupakan ciri kondisi peradangan. CBCT mampu menampilkan detail dari kondisi densitas dan histogram dari kamar pulpa. Densitas diukur menurut skala Hounsfield, yang merupakan suatu prinsip untuk sinar-X pada CBCT. Densitas suatu jaringan digambarkan dalam sebuah histogram citra berupa grafik yang mewakili frekuensi kemunculan relatif dari nilai piksel suatu citra. ${ }^{12}$ Jika semua data dalam populasi dikumpulkan lalu dibuat daftar distribusi dan kurva frekuensinya, maka kurva ini dapat menjelaskan kerakteristik populasi data yang diperoleh. Kurva ini merupakan model populasi yang akan menjelaskan berbagai ciri populasi. ${ }^{13}$ Gambaran histogram memuat data mengenai gambaran radiografi yang diambilnya dan memungkinkan dibuat diagnosis yang kuantitatif. ${ }^{14}$

Atas dasar pemikiran tersebut, perlu dilakukan penelitianuntukmenemukan gambaran nilai densitas dan histogram dari kamar pulpa pada gigi dengan kondisi pulpits reversibel dan pulpitis ireversibel menggunakan CBCT.

\section{BAHAN DAN METODE}

Penelitian deskriptif ini diharap menghasilkan data kuantitatif dari populasi yang digunakan yaitu data radiografi CBCT-3D pasien yang datang ke Rumah Sakit Gigi dan Mulut Fakultas Kedokteran Gigi Universitas Padjajaran selama tahun 2012-2013. Sampel adalah semua data CBCT gigi dengan suspek pulpitis reversibel dan ireversibel yang memenuhi kriteria yang ditetapkan yaitu 1) gigi molar pertama dankedua, dan gigi premolar pertama dan kedua yang kamar pulpanya terlihat jelas, 2) lebar dan tinggi kamar pulpa minimal 2,5 $\mathrm{mm}$ agar dapat dilakukan penentuan wilayah (ROI) dari histogram, 3) kamar pulpa tidak terdapat lesi lain seperti lesi radio-opak sehingga tidak mengganggu penilaian serta data radiografi CBCT-3D gigi pasien perempuan dan laki-laki yang berada pada rentang usia 17-55 tahun.

Variabel yang diteliti dalam penelitian iniadalah densitas, histogram yang terdiri dari perbandingan grayscale dan peak, trend, dan Hounsfield unit $(\mathrm{Hu})$; sedangkan penyakit sistemik yang mungkin diderita oleh penderita, kondisi kebersihan mulut dan jenis kelamin pasien diabaikan.

Pengukuran densitas diperoleh dengan menarik garis profil di kamar pulpa sepanjang $1 \mathrm{~mm}$ (Gambar 1) dari bidang korona dan sagital (Gambar 2). Diukur dua kali agar diperoleh angka yang terpercaya.

Nilai densitas ditentukan dengan menjumlah batas atas dan batas bawah lalu dibagi dua, dengan satuan Hounsfield unit $(\mathrm{Hu})$. Nilai tersebut secara langsung ditunjukkan oleh perangkat lunak yang digunakan. $^{15}$

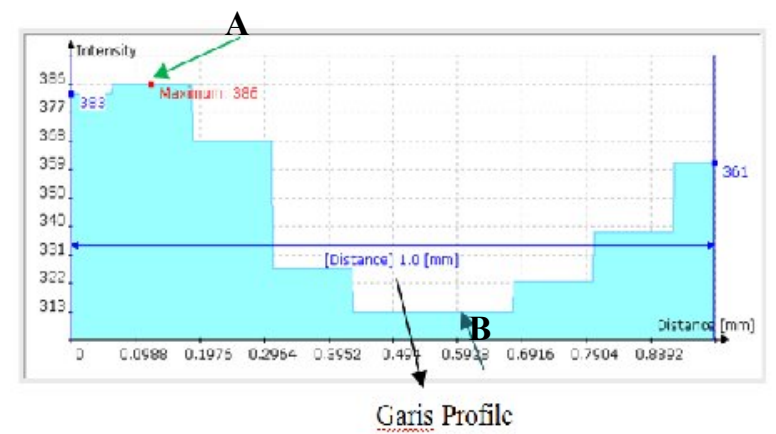

Gambar 1 Gambaran densitas setelah garis profil diambil sepanjang $1 \mathrm{~mm}$, batas atas ditunjukkan oleh panah (A) sedangkan batas bawah ditunjukkan oleh panah (B)
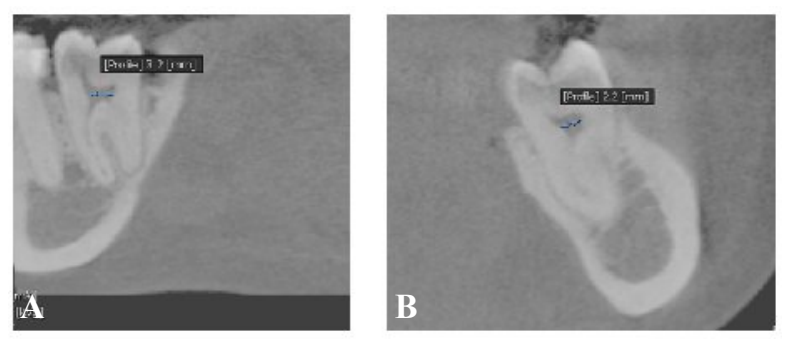

Gambar 2 Garis profil yang digunakan untuk mengukur densitas kamar pulpa; A pengambilan profil dari tampak korona, B pengambilan profil dari tampak sagital

Pengukuran histogram dengan menentukan ROI 1x1 mm(Gambar 3), sepanjang kamar pulpa dariarah korona; ROI yang diperoleh dalam satu kamar pulpa sebanyak 2 buah. Kemudian ditentukan data yang mendukung trend, peak dan grayscale. Nilai untuk setiap pengukuran akan muncul secara langsung di layar komputer. Nilai distribusi grayscale adalah area 
A apabila distribusi berada pada rentang $>0$ (Kelas I), area $\mathrm{B}$ distribusi berada pada rentang 0-215 (Kelas II), area C distribusi berada pada rentang 216-415 (Kelas III), dan area D distribusi berada pada rentang $>415$ (Kelas IV). ${ }^{63}$
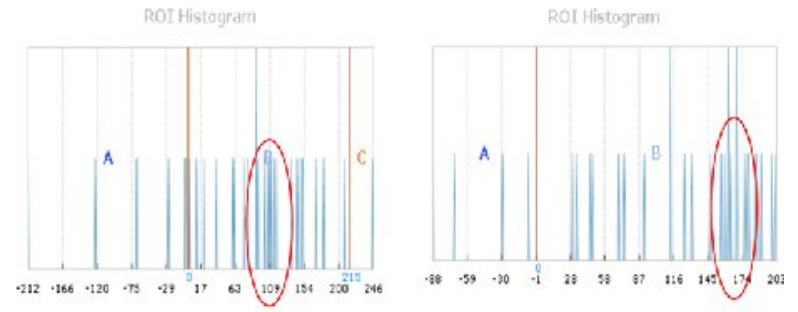

Gambar 3 Gambaran histogram dengan ROI 1x1 mm; histogram yang berada dalam lingkaran menunjukkan nilai grayscale dengan akumulasi terbanyak

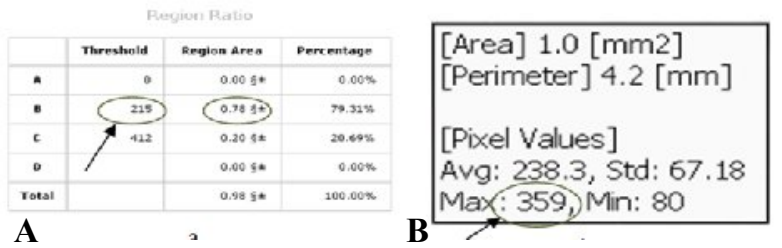

Gambar 4A Angka grayscale dengan distribusi terbesar, B nilai peak yang distribusi vertikalnya menunjukkan angka terbanyak

Penelitian ini diawali dengan pengumpulan data radiografi $\mathrm{CBCT}$ yang memenuhi kriteria kemudian menentukan nilai profil dan $\mathrm{ROI}(1 \mathrm{x} 1 \mathrm{~mm})$ dari setiap gigi mulai dari pulpitis reversibel dan ireversibel. Pengambilan ROI dilakukan pada tiga tempat, yaitu dua tempat pada tampak korona dan satu tempat pada tampakan sagital, lalu pengukuran dilakukan dua kali. Nilai ini dirata-ratakan untuk memperoleh satu nilai, lalu dianalisis nilai histogram dan profil. Pengukuran dilakukan pada tampakan korona dan sagital yang dilakukan sebanyak duakali pengukuran kemudian data dirata-ratakan (Gambar 5).

Alat yang digunakan adalah pesawat sinar-X jenis Picasso Trio; merek Epx-Impla, type B applied part Impla, no seri 0165906; produksi Vatech \& Ewoo Korea.Prosesor yang digunakan untukmengolah data adalah unit komputer Axio dengan spesifikasi Pentium 4, memori 4G. Soft-ware yang digunakan adalah Program EasyDent 4 Viewer (Vatech \& Ewoo Korea).

\section{HASIL}

Hasil pengukuran histogram terhadap kamar pulpa dengan 3 kondisi, ternyata memiliki perbedaan pada trend, distibusi grayscale, dan peak. Nilai peak adalah nilai dari distribusi data terbanyak dalam arah sumbu vertikal, semakin tingginilai peak berarti data dengan nilai yang sama berjumlah cukup banyak sehingga lebar histogram berkurang.Pada penelitian ini, nilai peak kamar pulpa normal menunjukkan penurunan sebesar sebesar 13,6\% dari angka 345,55 menjadi 298,3 pada pulpitis reversibel, sedangkan pada pulpitis ireversibel menurun $38,9 \%$, yaitu 210,9 (tabel 1). Hal ini berarti bahwa pada kondisi normal memliki distribusi data dengan nilai grayscale yang sama, cukup banyak dan tidak banyak data dengan nilai grayscale yang berbeda; diartikan bahwa pada kondisi pulpa normal, jaringan memiliki kepadatan yang sama atau merata. Perbedaan terlihat pada kamar pulpa dengan pulpitis reversibel dan pulpitis ireversibel nilai peak menurun, berarti data grayscale lebih menyebar terutama pada pulpitis ireversibel yang berarti pada kondisi jaringan pulpitis ireversibel memiliki densitas yang berbeda bila dibandingkan dengan pulpitis reversibel (tabel 2).

Hasil pengukuran histogram terhadap kamar pulpa dengan 3 kondisi ternyata memiliki perbedaan, baik pada trend, distribusi grayscale dan peak. Nilai peak adalah nilai dari distribusi data terbanyak dalam arah sumbu vertikal; semakin tinggi nilai peak berarti data dengan nilai yang sama berjumlah cukup banyak sehingga lebar histogram berkurang.Pada penelitian ini nilai peak kamar pulpa normal menunjukkan penurunan sebesar 13,6\% dari angka 345,55 menjadi 289,3 pada pulpitis reversibel, sedangkan jika pulpitis ireversibel menurun 38,9\%, yaitu 210,9 (tabel 1). Hal ini dapat diartikan bahwa pada kondisi normal memliki distribusi data dengan nilai grayscale yang sama cukup banyak dan tidak banyak data dengan nilai grayscale yang berbeda; artinya pada pulpa normal,jaringan memiliki kepadatan yang sama atau merata. Sedangkan perbedaan terlihat pada kondisi
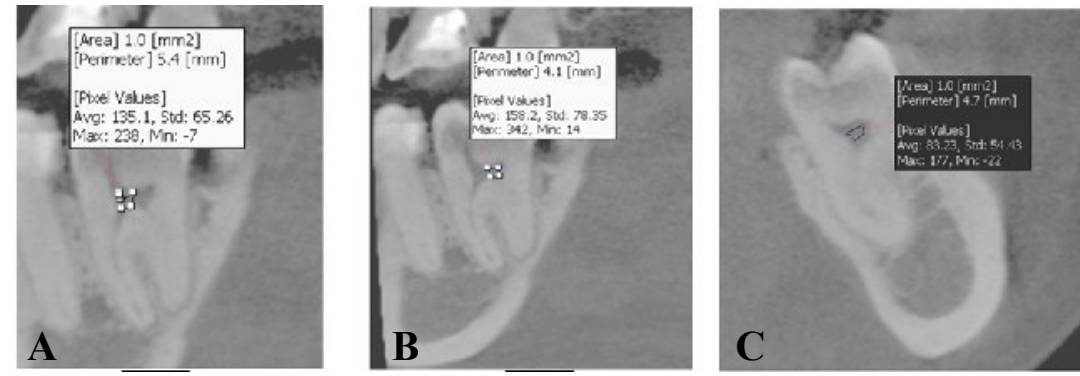

Gambar $\overline{5 \text { A }}$ dan B ROI 1x1 dari tampak korona yang diukur untuk menilai histogram, C ROI 1x1 dari tampak sagital yang diukur untuk menilai histogram 
kamar pulpa dengan pulpitis reversibel dan pulpitis ireversibel; nilai peak menurun yang berarti data grayscale lebih menyebar terutama pada pulpitis ireversibel yang berarti pada kondisi jaringan pada pulpitis ireversibel memiliki densitas yang berbeda bila dibandingkan dengan pulpitis reversibel.

Tabel 1 Nilai densitas kamar pulpa (Hu)

\begin{tabular}{|c|c|c|c|}
\hline Kondisi gigi & Batas Atas & Batas Bawah & Densitas \\
\hline Normal & 345,55 & 221,44 & 288,56 \\
\hline Pulpitis Reversibel & 289,3 & 155,08 & 222,2 \\
\hline Pulpitis Ireversibel & 210,9 & $-5,2$ & 102,81 \\
\hline
\end{tabular}

Tabel 2 Perhitungan signifikansi untuk nilai densitas

\begin{tabular}{clc}
\hline Kelompok & Kelompok Banding & Signifikansi \\
\hline \multirow{2}{*}{ Normal } & Pulpitis Reversibel & 0,01 \\
& Pulpitis ireversibel & 0,01 \\
\hline Pulpitis & Normal & 0,01 \\
Reversibel & Pulpitis ireversibel & 0,01 \\
\hline Pulpitis & Normal & 0,01 \\
Ireversibel & Pulpitis Reversibel & 0,01 \\
\hline
\end{tabular}

Secara statistik ternyata nilai peak pada kondisi normal terhadap pulpitis reversibel dan ireversibel signifikan berbeda $(\alpha=0,05)$, dan pulpitis ireversibel terhadap pulpitis reversibel signifikan berbeda juga dengan nilai kepercayaan lebih besar $(\alpha=0,01)$ (tabel 2). Terlihat untuk nilai peak terdapat perbedaan pada setiap data baik normal, pulpitis reversibel maupun pulpitis ireversibel (tabel 3 dan 4).

Tabel 3 Nilai puncak histogram (peak)

\begin{tabular}{ccc}
\hline Kondisi gigi & Nilai Puncak & \% penurunan \\
\hline Normal & 345,55 & 100 \\
Pulpitis Reversibel & 298,3 & 13,6 \\
Pulpitis Ireversibel & 210,9 & 38,9 \\
\hline
\end{tabular}

Tabel 4 Analisis nilai signifikansi untuk peak

\begin{tabular}{clc}
\hline Kelompok & Kelompok Banding & Signifikansi \\
\hline Normal & Pulpitis Reversibel & 0,05 \\
& Pulpitis ireversibel & 0,01 \\
\hline Pulpitis Reversibel & Normal & 0,05 \\
& Pulpitis ireversibel & 0,01 \\
\hline Pulpitis ireversibel & Normal & 0,01 \\
& Pulpitis Reversibel & 0,01 \\
\hline
\end{tabular}

Nilai lain yang dapat ditentukan dari penelitian ini adalah distribusi grayscale dan trend. Data yang diperoleh terlihat bahwa nilai distribusi pada kondisi pulpitis reversibel tersebar pada skor area $\mathrm{B}, \mathrm{D}$ dan $\mathrm{C}$ (tabel 5). Distribusi data didominasi pada skor 3 atau area $C$ dengan nilai maksimal 59,31, hampir sama dengan kontrol dengan skor pada area $\mathrm{C}(54,9)$. Akan tetapi, perbedaan area terlihat pada kondisi pulpitis ireversibel dengan daerah maksimal terdapat pada area skor 2 tepatnya pada area $\mathrm{B}$ dengan nilai 65,06. Data tersebar pada area A dan C. Hal ini dapat diartikan bahwa pada kondisi kamar pulpa normal dan pulpitis reversibel distribusi data dengan nilai grayscale hanya didominasi data dengan nilai 216415 , dan data dengan nilai $>415$. Ini berarti kondisi jaringan kamar pulpa memiliki kepadatan yang lebih tinggi bila dibandingan dengan pulpitis ireversibel yang hanya memiliki distribusi nilai grayscale terbesar pada $0-215$, hanya sebagian bernilai 216415 , bahkan ada yang bernilai $<0$, dan tidak ada data yang bernilai $>415$. Pada kondisi pulpitis ireversibel telah terjadi perubahan jaringan sehingga gambaran menjadi lebih luscent.

Uji statistik membuktikan bahwa pada kondisi kamar pulpa normal tidak signifikan berbeda dengan pulpitis reversibel baik pada area $\mathrm{A}, \mathrm{B}$, dan $\mathrm{C}$ (tabel 6), yaitu $A: \alpha=1$; $B: \alpha=0,997$; dan $C: \alpha=0,697$. Hal yang berbeda ditunjukkan pada nilai signifikansi kondisi normal terhadap pulpitis ireversibel yang menunjukkan signifikansi berbeda baik pada nilai reversibel baik pada area A, B, dan C, yaitu A: $\alpha=0,03$; B: $\alpha=0,01$; dan $C: \alpha=0,01$. Nilai yang sama tampak pada kondisi pulpitis reversibel terhadap pulpitis ireversibel yang menunjukkan signifikansi $\alpha=0,01$ baik pada area $\mathrm{A}, \mathrm{B}$, maupun $\mathrm{C}$, yaitu nilai untuk keseluruhan area.

Tabel 5 Distribusi grayscale kamar pulpa

\begin{tabular}{ccccc}
\hline Kondisi gigi & A & B & C & D \\
\hline Normal & 0 & 37,55 & 54,9 & 8,55 \\
Pulpitis Reversibel & 0 & 36,77 & 59,13 & 4,47 \\
Pulpitis Ireversibel & 24,95 & 65,06 & 14,01 & 0 \\
\hline
\end{tabular}

Berdasarkan nilai grayscle ini maka dapat ditentukan bahwa nilai trend untuk tiap kondisi seperti tampak pada tabel 7 .

Hasil penelitian memberikan data bahwa pada kondisi normal dan pulpitis reversibel, trend dari histogram cenderung ke kiri atau lebih radio-opak

Tabel 6 Analisis nilai signifikansi untuk grayscale

\begin{tabular}{llccc}
\hline \multicolumn{1}{c}{ Kelompok } & Kelompok Banding & \multicolumn{3}{c}{ Signifikansi } \\
\hline Normal & & A & B & C \\
& Pulpitis Reversibel & 1 & 0,997 & 0,697 \\
& Pulpitis ireversibel & 0,01 & 0,033 & 0,01 \\
\hline Pulpitis Reversibel & Normal & 1 & 0,997 & 0,697 \\
& Pulpitis ireversibel & 0,01 & 0,01 & 0,01 \\
\hline Pulpitis ireversibel & Normal & 0,01 & 0,01 & 0,01 \\
& Pulpitis Reversibel & 0,01 & 0,01 & 0,01 \\
\hline
\end{tabular}


Tabel 7 Nilai trend

\begin{tabular}{ccccc}
\hline Kondisi gigi & Nilai Grayscale & Area & Trend & Nilai \\
\hline Normal & 54,9 & C & III & $215-415$ \\
'Pulpitis Reversibel & 59,13 & C & III & $215-415$ \\
Pulpitis Ireversibel & 65,06 & B & II & $0-215$ \\
\hline
\end{tabular}

dibandingkan dengan pulpitis ireversibel, sedangkan pada kondisi pulpitis ireversibel terjadi pergeseran trend ke arah kanan yang berarti lebih radiolusen.

\section{PEMBAHASAN}

Diagnosis penyakitpulpa biasanya tidak mudah dilakukan karena gejalanya tidak jelas dan sangat sulit mengakses pulpa untuk uji klinis. Kondisi ini dipersulit oleh nyeri gigi yang berasal dari jaringan selain pulpa. Diagnosis yang tidak akurat dapat berakibat perawatan yang tidak tepat, menyulitkan pasien, dan bahkan membingungkan dokter giginya. Pemahaman histofisiologi pada pulpa yang sehat, kemungkinan proses patologi yang mendasari nyeri pulpa, penilaian seksama terhadap riwayat nyeri, dan pemeriksaan klinik yang layak serta uji diagnosis dapatmembantu dokter gigi mencapai diagnosis yang akurat dan hasil perawatan yang posistif. Sebenarnya jaringan pulpa merupakan sistem pengingat untuk gigi. Sebuah kerusakan kecil di struktur gigi yang tidak mencapai dentin mungkin tidak menghidupkan sistem pengingat ini, tetapi pada saat dentin terbuka baik karena karies gigi atau trauma, sistem ini akan dimulai. Proses perusakan akan berlangsung sejalan dengan besarnya sensasi dan peradangan yang terjadi. Proses peradangan ini dikenal dengan nama pulpitis, akan tetapi untuk mendiagnosis pulpitis sangat sulit. ${ }^{17}$ Peradangan pada pulpa yang lebih dikenal dengan nama pulpitis terbagi menjadi dua kondisi, yaitu pulpitis reversibel dan pulpitis ireversibel.

Analisis nilai densitas dan histogram ternyata sangat membantu penegakan diagnosis pulpitis, sebab penilaian didasarkan pada perbedaan densitas dan histogram pada pemeriksaan. Densitas atau histogram merupakan gambaran radiodensitas yang adalah ketidakmampuan relatif elektromagnetiknya, khususnya sinar-X, saat melewati bahan tertentu. Radiolusen menunjukkan transparansi yang lebih besar suatu bahan yang menghambat jalannya radiasi elektromagnetik atau radiodens, yang berarti bahan tersebut padat. Radiodensitas juga dapat diukur menurut skala Hounsfield, yaitu suatu prinsip yang diaplikasikan pada computed tomography (CT scan). Dalam pencitraan, istilah radiolusen dan radio-opak dapat berhubungan dengan kepadatan jaringan atau kapasitas jaringan. Semakin radiolusen gambaran maka jaringan yang ada semakin tidak padat atau berubah strukturnya menjadi lebih cair mendekati densitas air, yaitu 0 HU. ${ }^{18}$
Dalam penelitian ini, diperoleh hasil densitas kamar pulpa kondisi normal menunjukkan angka 288,5,5 HU. Pada kondisi pulpitis reversibel belum terjadi perubahan secara nyata pada pulpa. Pada kenyataannya terdapat sedikit perbedaan densitas antara kamar pulpa normal dan pulpitis reversibel $50 \mathrm{HU}$. Hal ini diduga akibat ketidakhomogenan sampel pulpitis reversibel. Akan tetapi nilai yang berbeda terjadi pada kondisi pulpitis ireversibel yang menunjukkan angka densitas jauh di bawah nilai normal yaitu 102,81 HU. Hal ini membuktikan bahwa pada pulpa yang meradang mengalami perubahan densitas menjadi semakin radiolusen, artinya terjadi dua keadaan, yaitu jaringan menjadi tidak padat atau terjadi perubahan struktur; kadar airnya bertambah. Reaksi peradangan itu sebenarnya adalah peristiwa terkoordinasi dengan baik, dinamis dan berlanjut. Untuk menimbulkan reaksi radang maka jaringan harus hidup dan khususnya harus memiliki sirkulasi mikro yang fungsional, sehingga dimaksud dengan radang adalah rangkaian reaksi yang terjadi pada tempat jaringan cedera yang dalam prosesnya terjadi pelepasan histamin danzat-zat humoral lain ke dalam cairan jaringan sekitarnya. Hal inilah yang diduga menyebabkan perubahan densitas dari kamar pulpa yang meradang. ${ }^{19,20}$

Perubahan ini juga dapat dilihat dari gambaran histogram setiap jenis kondisi. Pada kondisi normal dan pulpitis reversibel ternyata nilai grayscale pada histogram menunjukkan angka yang terakumulasi pada area $\mathrm{C}$ yang bernilai 215-415 grayscale. Nilai yang berbeda ditunjukkan pada pulpitis ireversibel yaitu nilai grayscale bergeser menjadi area $\mathrm{B}$ dengan nilai0-215 grayscale.Perbedaan juga dilihat darinilai puncak pada histogram, yaitu pada kondisi normal 345,55 point. Pada kondisi pulpitis reversibel terjadi penurunan menjadi 298,3 point, sedangkan pada pulpitis ireversibel menjadi 210,9 point, yang berarti terjadi perubahan kondisi pada kamar pulpa yang diteliti. Angka grayscale 215-415 berarti distribusi data yang terkumpul pada area penelitian ROI $1 \times 1$ $\mathrm{mm}$, memiliki derajat grayscale yang serupa, yaitu terkumpul pada rentang 215-415 grayscale atau area C (kelas III), yang menunjukkan bahwa distribusi data yang memiliki trend ke arah kelas III yang ada di sebelah kanan pada histogram, berarti lebih opak dari kelas I dan II. Sedangkan kondisi yang berbeda terjadi pada pulpitis ireversibel, yaitu data berada pada area B atau kelas II, artinya bahwa data yang 
terkumpul pada saat penelitian dengan ROI $1 \times 1 \mathrm{~mm}$ berada pada rentang 0-215 grayscale atau area B. Hal itu menandakan bahwa pada saat pengambilan data dilakukan, kondisi kamar pulpa lebih radiolusen atau trend bergeser ke kelas II yang lebih radiolusen.

Nilai peak pada pulpa normal bernilai 345,55 ; ini berarti penyebaran data cenderung memiliki nilai yang homogen yang penyebarannya berada pada area $\mathrm{C}$, dan sedikit pada area $\mathrm{B}$, bahkan tidak ada data pada area D. Nilai yang berbeda ditunjukkan pada kondisi pulpitis reversibel yang distribusi datanya memiliki nilai lebih rendah dari kondisi normal, yang berarti data tersebaratau homogenitasnya berkurang. Akan tetapi penyebaran data ini tetap ada pada area yang sama dengan kondisi normal yaitu pada area $C$, sedikit pada area B, dan A. Perbedaannya terlihat dari pergeseran trend pada histogram yang bergeser ke arah radiolusen meskipun pergeserannya tidak cukup berarti secara statistik $(\alpha=0,997)$ yang mendekati nilai 1. Hal yang berbeda ditunjukkan oleh kondisi pulpitis ireversibel baik terhadap kondisi normal ataupun pulpitis reversibel, yaitu nilai peak menunjukkan penurunan, distribusi data lebih heterogen dengan penyebarantersebarpada area A, B,C dan sedikitpada area D. Secara statistik terbukti signifikan berbeda $(\alpha=0,01)$ dengan pergeseran trend lebih ke arah kiri atau lebih radiolusen. Perubahan tersebut sebenarnya sesuai dengan teori peradangan yang menjelaskan bahwa pada kondisi peradangan ada beberapa gejala yang dapat menimbulkan perubahan densitas pada kamar pulpa. Awal peradangan secara garis besar ditandai dengan vasodilatasi pembuluh darah lokal yang mengakibatkan terjadinya aliran darah setempat yang berlebih, kenaikan permeabilitas kapiler disertai dengan kebocoran sejumlah besar cairan ke dalam ruang interstisial, pembentukan cairan dalam ruang interstisial yang disebabkan oleh fibrinogen dan protein lain yang bocor dari kapiler dalam jumlah berlebihan, migrasi sejumlah besar granulosit dan monosit ke dalam jaringan, dan pembengkakan sel jaringan. Beberapa produk jaringan penyebab reaksi tersebut adalah histamin, bradikinin, serotonin, dan prostaglandin, serta beberapa macam produk reaksi sistem komplemen, produk reaksi sistem pembekuan darah, dan berbagai substansi hormon seperti limfokin yang dilepas oleh sel $\mathrm{T}$ yang tersensitisasi. Apabila dijabarkan, proses radang diawali dengan terjadinya vasodilatasi lokal dari arteri dan kapiler sehingga plasma merembes keluar. Selanjutnya cairan edema terkumpul di daerah sekitar luka, kemudian fibrin membentuk sejenisjala yang akan menutupi saluran limfe sehingga penyebaran mikroorganisme dapat dibatasi. Dalam proses inflamasi juga terjadi proses fagositosis, yaitu fagosit membungkus organism mikro, kemudian dimulailah proses digesti dalam sel. Hal ini mengakibatkan perubahan $\mathrm{pH}$ menjadi asam. Selanjutnya keluar protease seluler yang akan menyebabkan leukosit lisis. Setelah itu makrofag mononuclear yang besar tiba di lokasi infeksi untuk membungkus sisa leukosit. Pada akhirnya terjadilah pencairan hasil proses inflamasi lokal. Eksudat adalah cairan radang ekstravaskular dengan berat jenis tinggi (di atas 1.020), cairan kaya protein dan sel darah putih yang tertimbun di dalam ruang ekstravaskular akibat reaksi radang, mengandung protein $2-4 \mathrm{mg} \%$ serta sel-sel darah putih yang melakukan emigrasi. Cairan ini tertimbun akibat permeabilitas pembuluh darah yang memungkinkan protein plasma dengan molekul besar dapatterlepas. ${ }^{21}$ Proses tersebut yang diduga menyebabkan perubahan pada densitas dan nilai histogram pada penelitian ini.

Densitas dan histogram suatu image ternyata sangat membantu dalam membedakan diagnosis suatu kelainan. Hal ini telah dibuktikan oleh beberapa peneliti terutama dalam penelitian yang dilakukan pada kualitas tulang. Akan tapi perlu disadari bahwa penelitian ini jauh dari kesempunaan, karena banyak sekali kekurangan yang disadari diantaranya 1) data awal kondisi kamar pulpa hanya berdasar diagnosis radiografi tanpa dikonfirmasikan pada kondisi klinis pasien dan ahli endodontik, sehingga dapat menjadi perancu pada penelitian, 2) data yang diteliti kurang mewakili, 3) sampel terlalu heterogen karena tidak dilakukan pengelompokan, dan 4) jumlah sampel kurang banyak dan kurang mewakili.Untuk itu perlu dilakukan penelitian lanjutan dengan keakuratan dan ketelitian yang lebih baik. Akan tetapi penelitian ini dapat data awal atau acuan awal peneliti selanjutnya.

Berdasarkan hasil penelitian ini, disimpulkan bahwa gambaran nilai densitas kamar pulpa secara signifikan berbeda antar kondisi normal, pulpitis reversibel dan pulpitis ireversibel; nilai pada pulpitis ireversibel lebih radiolusen dibandingkan dengan kondisi normal dan pulpitis reversibel. Sedangkan dari data histogram berdasar nilai peak, grayscale, dan trend secara signifikan terbukti menunjukkan perbedaan yaitu pulpitis ireversibel menunjukkan pergeseran lebih radiolusen dengan penyebaran data lebih heterogen dibandingkan pulpitis reversibel dan normal.

\section{DAFTAR PUSTAKA}

1. Soebroto. Apa yang tidak dikatakan dokter tentang kesehatan gigi anda. Jogjakarta: Bookmarks; 2009

2. Taringan R. Perawatan pulpa gigi. Edisi ke-2. Jakarta: Hipokrates; 2004 
3. Jhon B. Mengenal gigi anda. Jakarta: Arcan; 1996

4. Karies Gigi. Diunduh dari 2006. Diakses pada tanggal 19 April 2013

5. Taringan R. 2006. Karies Gigi. Jakarta: Hipokrates

6. Riset Kesehatan Dasar Depkes RI. Diunduh dari www. Depkes.com [2007]. Diakses pada tanggal 19 April 2013

7. Pulpitis the Aberdeen. Diunduh dari http://id.Wikipedia.org.com [2003]. Diakses pada tanggal 19 April 2013

8. Michaelson PL, Holland GR. Pulpitis pain. Endodont J Int 2002; 35: 829-32

9. Seltzer S, Bender IB. Dental pulp. Editor: Hargreaves KM. Goodis HE. Chichago: Quintessence Publish; 2002

10. Carranza's. Clinical Periodontology. $9^{\text {th }}$ Ed. Philadelphia: W.B. Saunders; 2002. p. 435

11. Torabinejad M, Walton. Endodontics: principles and practice. $4^{\text {th }}$ Ed. Elsevier Health Sciences; 2008

12. Byers MR, Suzuki H, Maeda T. Dental neuroplasticity, neuro-pulpal interactions, and nerve regeneration. Microsc Res Tech J 2003; 60: 503-15

13. Muhtadan, Djiwo H . Pengembangan aplikasi untuk perbaikan citra digital film radiografi. Yogyakarta: Sekolah Tinggi Teknologi Nuklir. Diakses dari http://jurnal.sttn-batan.ac.id/[2008]. Diakses 19 April 2013

14. Sudjana. Metoda statistika. Edisi ke-6. Bandung: PT. Tarsito; 2005

15. Riyanto A. Alikasi Metodelogi Penelitian Kesehatan. Yogyakarta Nuba Medica; 2011

16. Current Product Picaso Trio. Disadur dari www. Vatech.com [2008]. Diakses: Februari 2011

17. Susanti MI. Statistika deskriptif dan induktif. Yogyakarta: Graha Ilmu; 2010

18. Novelline R. Squire's fundamentals of radiology. Edisi ke-5. Harvard: Harvard University Press; 1997

19. Dorland. Kamus kedokteran. Edisi ke-31. Jakarta: EGC; 2002

20. Katzung BG. Farmakologi dasar dan klinik. Edisi ke-2. Jakarta: Salemba Medika; 2002. p.671, 677-8

21. Cotran RS, Michel MD, Ramzi S, Richard N. Jejas, adaptasi dan kematian sel. Dalam: Robins pathologic basic of disease. Edisi ke-7. Alih bahasa: Prasetiyo A, Pendit UB, Priliono T. Volume 1. Jakarta: EGC; 2003. p.3-28 